\title{
Bridging Regionalism and Secessionism: Territorial Autonomy Movements in the Iberian World
}

\author{
Matthias vom Hau* and Hana Srebotnjak \\ Institut Barcelona d'Estudis Internacionals, Barcelona, Spain \\ *Corresponding author. Email: mvomhau@ibei.org
}

\begin{abstract}
In comparative works on nationalism Latin America is usually portrayed as a world region that is devoid of nationalist and separatist movements, while in Europe nationalist movements seeking greater self-determination or separate statehood can be easily observed. This article takes a different perspective. Applying the concept of territorial autonomy movements, it pursues a cross-regional comparison of Santa Cruz in Bolivia, Guayas in Ecuador, and Catalonia in Spain to show that movements strikingly similar with regards to their core claims, diagnostic frames, and tactics do in fact exist across the Iberian world. The chapter then draws on social movement theory to account for the recent intensification of territorial autonomy mobilizations in these cases. We argue that in all three substate units (1) threats of political exclusion emanating from contestations over established power-sharing arrangements triggered territorial grievances; (2) the formation of dense associational networks and new alliances with subnational party and state representatives enhanced the organizational resources of territorial challengers; and (3) broader protest cycles, and their concern with direct democracy and/or multicultural group rights, provided territorial challengers with new framing strategies to justify their demands.
\end{abstract}

Keywords: nationalism; autonomy; secessionism; social movements; Latin America; Spain

\section{Introduction}

In comparative works on nationalism, Latin America is usually portrayed as a world region that is devoid of nationalist and separatist movements (Centeno 2002; Mares 2001; Wimmer and Min 2009). The lack of counter-state nationalism in Latin America tends to be compared to Europe where nationalist movements seeking greater self-determination or even separate statehood can be easily observed. State-challenging mobilizations in Latin America that do involve claims for autonomy and self-government tend to be subsumed under different sets of regionally bounded bodies of research. Historical movements for more territorial self-determination are analyzed as instances of regionalism (Gootenberg 1991; Rubin 1997; Soifer 2016) while more recent manifestations of these kinds of claims are usually understood as an integral part of indigenous politics (Yashar 2005; Lucero 2008; Trejo 2012). 
The more general trend that this juxtaposition between Latin America and Europe builds on but also reinforces is the relative absence of systematic dialogue between literatures on regionalism and secessionism. Analysts of the latter tend to treat state-seeking nationalism as phenomenon sui generis to be compared to other instances of secessionist mobilization (Bolton and Roland 1997; Coggins 2014; Hechter 1992). In fact, scholarship on secessionism tends to be primarily concerned with explaining variations in the intensity or risk of separatist claims (Laitin 2001; Lustick et al. 2004; Sorens 2005), while sidestepping that demands for more self-rule do not necessarily imply the creation of a separate state. Moreover, the existing scholarship also tends to reproduce the high level of (world-regional) compartmentalization in the study of regionalism with individual cases usually only compared to other cases within their respective world-regional contexts.

In this article we take a radically different approach. We treat both regionalism and stateseeking nationalism as instances of territorial autonomy movements that are concerned with transforming the existing organization of state space. There are several reasons for this conceptual move. For starters, at the level of international law, demands for self-rule may refer to a variety of different arrangements, including secession but also cantonal arrangements and asymmetric federalism. The United Nations Charter (1945) for example treats territorial autonomy as synonymous with "self-government," without further specifying an inherent connection to sovereignty or independence (Cornell 2002, 249). Moreover, from a contentious politics perspective regionalist and separatist movements share important similarities with respect to their basic organizational characteristics and tactics. Both imply the presence of a territorially based political cleavage between the central state and some spatially defined subnational identity category or group (Núñez 1999). And both engage in "territorial work" (Lopes de Souza 2016, 1297) by politicizing socio-spatial identities and designating particular territories as spaces of collective mobilization and political unity. Seen in this light, we propose to use territorial autonomy movements as an umbrella concept that allows us to capture mobilizations whose claims for greater political and administrative power over a substate unit vary from regionalist to separatist demands. 
Equipped with this analytical lens we pursue one of the first systematic cross-regional comparisons, focusing on territorial autonomy movements in Bolivia, Ecuador, and Spain that have previously never been compared to each other. During the 2010 s state-seeking nationalist mobilization became a staple in Catalonia. Mass demonstrations and other protests regularly attracted more than one million participants. While outright separatist nationalism cannot be observed in Latin America, several countries in the region have seen movements that are strikingly similar to Catalan secessionist mobilization. Most prominently, during the 2000s sustained protests in Bolivia's Santa Cruz and Ecuador's Guayas region combined claims for greater fiscal autonomy and control over tax revenues with claims for far-reaching political autonomy. Both movements justified their demands by claiming to represent a territorially defined community that is also culturally distinct from the rest of the country. And again similar to Catalan secessionism, they employed a mixture of mass demonstrations, public rallies, festive parades, and other cultural performances to insert their claims into the public sphere.

What explains this recent intensification of territorial autonomy mobilization in Santa Cruz and Guayas during the 2000s and in Catalonia during the 2010s? The explanatory argument developed in this article builds and expands on Kent Eaton's (2011) seminal study of Bolivia and Ecuador and employs social movement theory. Our theoretical framework suggests that in all three cases certain structural opportunities, most importantly long-run within-country inequalities between different subnational units and asymmetries in economic and political power, facilitate the emergence of territorial autonomy movements, but that those conditions are by themselves not enough to account for the recent intensification of mobilization. We further argue that threats of political exclusion emanating from conflicts over established territorial arrangements motivated mobilization, while changes in movement infrastructure provided new organizational resources. Lastly, the transformation of framing strategies, and broader changes in political language and discursive repertoires associated with them, enhanced the legitimacy of protest activities by territorial challengers. 
Our argument is further strengthened when important differences between the three cases are considered. The first concerns the political ideology of the respective central government targeted by territorial autonomy activism. While movements in Santa Cruz and Guayas sought to defend their territorial interests against the leftist-populist governments of Evo Morales (2006-2019) and Rafael Correa (2007-2017), mobilization in Catalonia intensified under the right-of-center government led by Mariano Rajoy (2011-2018). Second, the ideological orientation of the movements themselves varied. Whereas the Catalan territorial autonomy movement has been ideologically diverse - with support from across the left-right political spectrum, autonomy movements in Santa Cruz and Guayas have been firmly right-wing in their political ideology. The third difference has to do with institutional design. In Spain, decentralization reforms after democratization led to the creation of autonomous regions as the most relevant substate unit, while in Bolivia and Ecuador decentralization efforts prioritized municipalities. Last but not least, the three cases vary with respect to the wider institutional context in which territorial autonomy activism unfolded. When compared to its counterparts in Santa Cruz and Guayas, the movement in Catalonia has operated within the confines of an administratively stronger and infrastructurally more powerful central state, and the supranational structure of the European Union (EU).

These striking ideological, political, and institutional differences between Santa Cruz, Guayas, and Catalonia further reinforce our focus on threats, resources, and framing strategies as a novel and compelling perspective to explain the recent intensification of territorial autonomy movements in the three cases. Using social movement theory to conduct this cross-regional comparison also allows us to engage in a variety of broader debates. It offers a novel inter-regional perspective for scholars of state-seeking nationalism in Europe and regionalism in Latin America, by seeking to cross-fertilize the conceptual frameworks and causal arguments mostly based on regionally bounded comparisons from within each world region. Moreover, our study also provides more nuance to the explanatory arguments made by cross-national statistical studies of secessionist and regional autonomy movements. 
Before we proceed, it bears emphasis that our argument is not meant to provide an exhaustive explanation of the origins of these movements. Throughout the article we briefly trace the long-run emergence of territorial autonomy activism in each case, and the major factors involved in it. In Santa Cruz and Guayas those include long-established cultural differences and administrative divisions with other parts of Bolivia and Ecuador that are rooted in the colonial period (Mahoney 2010; Soifer 2016) and in the case of Catalonia, the historical spread of mass literacy in Catalan (Balcells 2013; Colomer 2017) and repeated episodes of territorial conflict with the Spanish central state that go back several centuries (Boix 2002). In the conclusion we also engage with the recent debate on what led the Catalan movement to change its position from autonomy to secession from the Spanish state. But the main focus of the present analysis remains on why territorial autonomy mobilization intensified in early $21^{\text {st }}$ century Santa Cruz, Guayas, and Catalonia, and what can be learned from bringing Catalan separatism and regionalist mobilization in Bolivia and Ecuador into a systematic conversation with each other.

The reminder of the article is organized accordingly. After developing the concept of territorial autonomy movement in greater detail we employ it to identify and compare patterns of contention in Santa Cruz, Guayas, and Catalonia. The next sections develop our cross-cutting explanatory factors empirically. The conclusion spells out broader implications and potential use of our analytical approach for cross-regional comparisons of territorial autonomy movements in other world regions.

\section{Territorial Autonomy Movements: Some Conceptual Clarifications}

In the existing scholarship Catalonia is often analyzed through the lens of nationalism. Together with Scotland and Quebec, it represents one of the quintessential examples of "nations without states" (Guibernau 1998) or "nations against the state" (Keating 1996) - and thus collective political actors that have become more assertive in challenging authority of the central state. Many of the most-cited comparative works published before 2010 also emphasize the relatively more inclusive and 
conciliatory nature of Catalan nationalist mobilization, while studies after 2010 increasingly focus on the recent intensification of secessionism in Catalonia (Barrio and Rodríguez-Teruel 2017; Basta 2018; Guibernau 2013).

The arguably rather sparse literature on Santa Cruz and Guayas draws on a different conceptual apparatus. The two are regularly categorized as regions and presented as paradigmatic examples of regionalism, with most studies either focused on historical roots of these mobilizations (Soifer 2016) or seeking to explain why regionalism has emerged in Bolivia and Ecuador but not elsewhere in Latin America (Eaton 2011). And echoing the trend identified for Catalonia, a growing body of work explores possible drivers of the intensification of regionalist mobilization in Santa Cruz and Guayas (Eaton 2007; Fabricant and Postero 2013; Gustafson 2006).

In this article we pursue a different approach. We study recent contentious episodes in Catalonia, Santa Cruz, and Guayas as territorial autonomy movements - or instances of subnational mobilization predicated on the presence of a center-periphery cleavage in the polity and concerned with transforming particular territories into spaces of collective identification and political organization that then provide the basis for claims to greater self-rule. This conceptualization captures both secessionist and non-secessionist variants of collective mobilization and thus enables us to explore both striking similarities and important differences between the three cases. Before we start our comparative analysis some further clarifications about why we use the labels "movement," “autonomy," and "territorial" are in order.

The concept of social movements refers to sustained forms of collective action that are articulated around a shared sense of mission and identity, and that challenge (or defend) existing authority structures (Tarrow 1998; Tilly 2005). This focus provides us with the analytical leverage necessary to differentiate between periodic protests and recognizable social movements with some degree of organization and continuity over time. It also enables us to draw a clear line of distinction to political parties and advocacy groups. While those collective actors might advance similar demands and claim to speak in the name of the same shared social identity, territorial autonomy movements 
primarily draw on non-institutionalized forms of political action. Moreover, a social movements perspective does not presuppose a shared identity. Rather, it is sustained mobilization itself that might produce a sense of belonging and collective identification among movement participants (Polletta and Jasper 2001).

Autonomy is a contested concept but, for our purposes, it provides important analytical advantages when compared to secessionism and regionalism as the dominant conceptual lenses used by existing scholarship on Catalonia, Santa Cruz, and Guayas. At the most basic level, autonomy is used to describe instances of collective action that seek to eschew any affiliation or engagement with an established political structure (Lopes de Souza 2016). Seen in this light, autonomy provides us with a language suitable to detect similarities between these in many ways very different social movements. As we develop in greater detail in the next section, all three movements resented the established fiscal pact with the central state and in response demanded greater control over distribution of state resources. The three movements have also used strikingly similar tactics in order to insert their claims into the public sphere.

Finally, we add the label "territorial" as an important qualifier to delineate, in broad strokes, the kind of autonomy movements we are interested in. Regardless of whether sustained collective mobilizations were oriented towards achieving sovereignty (as in Catalonia) or greater rights and control over resources within existing state structures (as in Bolivia and Ecuador), their aim was to alter the existing spatial organization of the polity. Most prominently, territorial autonomy movements are analytically distinct from cultural autonomy movements (Cornell 2002). The latter often claim to speak in the name of migrant communities or indigenous groups, and their demands are concerned with rights, recognition, and access to resources across national territory (and sometimes even world regions) and not a particular subnational territorial unit.

Equipped with this conceptual approach, the next section compares recent territorial autonomy movements in Catalonia, Santa Cruz, and Guayas. Specifically, we focus on protest episodes during the early $21^{\text {st }}$ century when collective mobilization intensified and map major 
similarities and differences in demands, tactics, composition, and organizational structure of these movements.

\section{Intensified Mobilization for Territorial Autonomy in Santa Cruz, Guayas, and Catalonia}

The proper division of resources and decision-making authority between the central state and substate units has long informed political debates in Santa Cruz, Guayas, and Catalonia. All three are an economic powerhouse but not the political center of their respective country. In fact, Spain, Bolivia and Ecuador are characterized by a significant disjuncture between the spatial location of political and economic power. Over the course of the $20^{\text {th }}$ century Santa Cruz became the center of Bolivia's natural and productive resources, yet despite its dominant economic position, political power has remained concentrated in the capital La Paz (Gustafson 2006; Eaton 2007). Ecuador's development has often been described as "a tale of two cities" (Chiriboga-Tejada 2018), with Guayaquil historically the country's economic and Quito its political center. Catalonia industrialized in the $19^{\text {th }}$ century, far ahead than the rest of Spain (with the exception of the Basque Country), yet political power remained concentrated in Madrid (Guibernau 2013).

On account of their successful economic development and high urbanization levels, Santa Cruz, Guayas, and Catalonia also experienced an influx of internal migrants from less developed regions. In Bolivia, the 1980s pro-market policies led to a reduction of mining jobs in the highland regions prompting a wave of migrants of mainly Aymaran and Quechan descent to emigrate to Santa Cruz (Eaton 2011). In Ecuador, the position of Guayas as the country's leading export and service provider attracted migrants from abroad as well as Ecuador's poorer highland and central regions, leading to a rapid and unequal expansion that is particularly evident in the city of Guayaquil (Delgado 2013). In Catalonia, a large influx of migrants from Spain's poorer regions occurred between the mid1950s and mid-1970s, turning immigrants into a demographic majority by 1975 (De la Calle and Miley 2008). In all three cases, the divide between migrants and "natives" subsequently became a useful tool of political mobilization. 
The common experience of migration and growing within-country inequalities certainly contributed to the formation of territorially based political cleavages and socio-spatial identities in the three cases. As a matter of fact, protests against the existing institutional order and demands for greater autonomy are nothing novel in these substate units. What has recently changed, however, is the intensity, form, and political contents of these demands: since the onset of the $21^{\text {st }}$ century, Catalonia, Santa Cruz, and Guayas have witnessed the formation of full-blown territorial autonomy movements. In all three cases contentious episodes unfolded that included a series of mass rallies and demonstrations in combination with media campaigns, education initiatives, and cultural work. Those are the main focus of this chapter.

In Santa Cruz a major contentious episode galvanized between 2003 and 2010. During those years marches and rallies regularly brought several hundred thousand participants onto the streets of the region's major urban centers to protest against Bolivia's territorial state organization. Most prominently, in January 2005 over 350,000 people demonstrated in favor of a referendum on regional autonomy, making this event Bolivia's largest demonstration ever. Other protest tactics involved regionally specific strikes and the selective use of road blocks but also politicization of cultural events such as carnivals and holiday parades. The movement has complemented these public performances with frequent media statements, education campaigns, and some highly publicized efforts to collect the necessary signatures for holding a referendum (Eaton 2011).

Guayas experienced a broadly similar period of intensified mobilization. From 1999 to 2008 the region saw frequent mass protests, particularly notable the 2005 so-called Marcha Blanca and the January 2008 demonstrations to defend Guayas' interests against Ecuador's then newly elected president Rafael Correa, attended by more than 200,000 people. Petitions, regional strikes, education campaigns focused on creating a sense of a distinct regional identity, and frequent media statements have equally formed a part of the action repertoire.

In Catalonia a comparable contentious episode unfolded during the 2010s. From 2010 until at least 2017, public demonstrations in favor of Catalan independence dominated protest cycles in the 
region. The movement also transformed the Diada - the National Day of Catalonia and a public holiday in the region - into a focal point of annual pro-independence rallies, with the $2013 \mathrm{Via}$ Catalana celebrations involving an estimated 1.6 million participants.

The main demands behind these sustained mass mobilizations in Catalonia have been centered on secession from Spain, which stands in sharp contrast to the other two regions. In Santa Cruz only the most radical flank of the territorial autonomy movement has advanced demands for secession and the formation of an independent national state. Otherwise, the vision of far-reaching political and economic independence within existing state structures dominate the movements in Santa Cruz and Guayas. But these differences in demands, which we briefly explain in the conclusion, should not distract from a number of striking similarities between the three cases.

Mass protests in Catalonia, Santa Cruz, and Guayas drew on similar diagnostic frames. That is, these territorial autonomy movements resembled each other in how they identified a problem and assigned blame to adversaries in order to motivate, construct meaning, and gain wider support for their protest activities (Snow et al. 1986). In all three cases, activists voiced deep concerns about the governance of center-substate relations, and recent challenges to it. Of particular concern were fiscal arrangements and the distribution of resources between national and subnational states. In Catalonia, movement factions perceived the existing fiscal pact as increasingly unjust, especially after the fallout of the Great Recession (2007-2009) made itself felt and the central government responded with a series of harsh austerity measures. This established an important backbone for secessionist claims: Catalonia would be much better off if it were independent and hence in charge of its own fiscal matters. A similar diagnostic frame has underpinned mass protests in Santa Cruz and Guayas. Both territorial autonomy movements suggested that their region had in fact been punished by the central government for being an economic powerhouse. Following this logic, Santa Cruz and Guayas appeared to over-subsidize the rest of Bolivia or Ecuador by paying a disproportionate share of tax revenues in comparison to other subnational regions. In response, movement proponents demanded greater fiscal and political autonomy. 
The three episodes of mass mobilization were also articulated around particular collective identities. In fact, these identities might have been developed - or at a minimum strengthened - in and through protest activities (Polletta and Jasper 2001). Whether in Catalonia, Santa Cruz, or Guayas, territorial challengers claimed to represent a territorially and culturally distinct subnational "imagined community" that has legitimate reasons to make claims on the central state. In Catalonia secessionists (and their organizations and networks) depicted themselves as the embodiment of the "Catalan nation" that is historically, culturally, and linguistically distinct from the rest of Spain. The Santa Cruz movement similarly emphasized its own distinct territorial identity, pointing to common cultural characteristics and historical experiences that are supposedly shared by all Cruceños (people from Santa Cruz) alike, regardless of their class and ethnic background. Proponents of the movement point to the region's distinct colonial history when it was a part of another administrative unit than La Paz and Bolivia's Andean region. Comparable patterns of territorial work can also be found in Ecuador. In Guayas, activists highlighted the region's unique customs of music, dance, speech and food, and its different colonial history as markers of distinction from the rest of Ecuador.

The cultural and territorial identities projected by these movements should not distract from distinct class backgrounds of the main actors involved in these contentious episodes. In Catalonia, mobilization in favor of greater territorial autonomy and/or secession from Spain was traditionally dominated by middle classes. Although the recent intensification of secessionist contention was built on a broader social base, the movement's greatest supporters continue to be middle-class while its greatest adversaries come from Catalonia's poorest and wealthiest segments (Hierro and Queralt 2021). Class distinctions were even more pronounced among activists in Santa Cruz and Guayas. The leaders of the main social movement organizations tended to be mestizo or white males and part of the respective region's economic or professional elite, with connections to landed wealth and experience in representing private sector interests. That being said, especially in Santa Cruz the territorial autonomy movement has taken steps to diversify its class composition by seeking to incorporate youth, women, and lowland indigenous groups. 
In sum, the contentious episodes taking place in $21^{\text {st }}$ century Catalonia, Santa Cruz, and Guayas represent instances of territorial autonomy movements. While their demands vary between outright secession (Catalonia) and greater political and fiscal autonomy within the existing territorial order (Santa Cruz and Guayas), challengers in all three settings draw on strikingly similar tactics, diagnostic frames, and territorial work to make their claims heard.

\section{Changes in Territorial Arrangements and Threats of Political Exclusion}

How then to explain the recent intensification of territorial autonomy mobilizations in Santa Cruz, Guayas, and Catalonia? Social movement theory suggests that close attention to the political context in which contentious collective action unfolds is warranted (McAdam 1982). Specifically, theorists of contentious politics have long emphasized the crucial role of political threats - or the likelihood that groups lose rights, experience state-attributed economic problems, and/or become marginalized within existing institutional arrangements if they do not act collectively (Tilly 1978; Almeida 2003) - to spur mobilization. Recent scholarship on ethnonationalist conflict comes to broadly similar conclusions: crossnational statistical work shows that political exclusion motivates ethnic and national minorities to engage in collective protest (Cederman, Wimmer, and Min 2010) while qualitative historical studies on the rise of anti-colonial nationalism indicate that nationalist mobilization was more likely in colonial territories where demands for political equality with the center were repeatedly ignored (Lawrence 2013; Wimmer 2002).

Building on these insights, we argue that threats of political exclusion resulting from conflicts over established power-sharing arrangements between substate units and the central state spurred territorial autonomy mobilization. During the mid-20 $0^{\text {th }}$ century Santa Cruz, Guayas, and Catalonia reached agreements that granted them significant control over subnational affairs and allowed them to also retain significant formal and/or informal influence over national politics. These territorial arrangements became increasingly contested in the $21^{\text {st }}$ century. Subnational elites lost trust in existing institutional agreements and feared their growing political marginalization, ultimately 
motivating territorial activism in favor of more self-government. In the upcoming paragraphs we will examine the agreements that were initially made in each country, recent changes to said arrangements, and the resulting threats of political exclusion.

\section{Santa Cruz}

In the second half of $20^{\text {th }}$ century Bolivia experienced frequent regime changes. Yet, regardless of whether the central government was authoritarian or democratic, Santa Cruz enjoyed significant control over fiscal and administrative matters while economic and political elites that dominated the region also held a substantial sway over national politics. To illustrate, when the left-leaning military government led by Juan José Torres (1970-1971) proposed nationalizing Bolivia’s sugar industry, Santa Cruz regional elites helped stage a coup against him, replacing him for a Santa Cruz native, colonel Hugo Banzer. Under his rule (1971-1978) 66\% of Bolivia's agricultural bank credit was directed to the region's agribusinesses, the majority of which was never repaid. And after the transition to democracy in 1982, the Movimiento Nacionalista Revolucionario (MNR) turned into a stronghold for Cruceño politicians as the party changed from a leftist-reformist to an increasingly pro-market stance, which directly benefitted the region's dominant economic sectors (Eaton 2011; Gustafson 2006).

This arrangement did not endure, and from 1990s onwards Santa Cruz's political power began to wane. Behind major institutional changes that underpinned this loss of influence was an ambitious reform agenda aimed at radically restructuring the central state. President Gonzalo Sánchez de Lozada (1993-1997) pursued far-reaching municipal decentralization. His reforms created and empowered municipalities as a new level of government, while they simultaneously reduced the importance of departments - previously governed by directly elected representative assemblies - by turning them into mere administrative units. Cruceño elites perceived this spatial reorganization of the state as a major threat to the established political settlement that would lead to the region's political exclusion from decision-making at the national level (Eaton 2007). 
Another threat that fueled mobilization for more regional autonomy emanated from the rise of an increasingly powerful new political actor: the Movimiento al Socialismo (MAS), a movement party under the leadership of Evo Morales. MAS emerged as a consequence of a series of social protests organized by indigenous groups, anti-neoliberal activists, and environmentalists. While support for traditional parties whose endorsement of neoliberal policies benefitted Santa Cruz elites fell dramatically, Evo Morales' MAS made a huge headway winning second place in the 2002 presidential elections and eventually winning the 2005 elections. Morales' victory profoundly transformed Bolivian politics and Santa Cruz elites perceived his government as an unprecedented threat. Indeed, MAS's position on the nationalization of Bolivia's gas industry and the need for a redistributive land reform, which would consequently benefit indigenous groups at the expense of wealthy landowners, further instigated demands for regional autonomy (Eaton 2007; Vergara 2012).

\section{Guayas}

Similar to Bolivia, the late $20^{\text {th }}$ century democratization of Ecuador introduced far-reaching decentralization efforts that granted local governments new responsibilities and control over public services. Yet, in contrast to Bolivia, the reforms actually strengthened the position of Guayas vis-àvis the central state, at least initially, as the new measures enabled larger and politically more powerful local governments to lobby the national government directly. The 1979 Constitution also prohibited subnational parties while making provinces act as electoral districts. Due to the regional nature of party support then, traditional parties that were henceforth expected to operate as national parties continued to represent the interests of territorially defined groups. For example, while formally a national party, the center-right Partido Social Cristiano (PSC) essentially became a regionalist party after democratization, winning all major elected offices in the coastal regions with Guayas representing its strongest support base. Furthermore, to gain access to state resources and make good on their electoral promises national parties began to regularly form alliances with authorities elected at the subnational level such as mayors and provincial governors. Ecuador's party politics thus 
became a struggle between different territories rather than a contestation over nationally relevant ideological and economic concerns (Pachano 2006).

That being said, Ecuador's decentralization reforms came with a catch that ultimately contributed to the decline of Guayas' political influence on national politics. Specifically, the rather contradictory and unstable arrangements between the local and national level made national policymaking very difficult. Central state paralysis that followed further reinforced distinct regional identities and permitted local politicians to rely on clientelistic practices. In addition, the financial crisis of 1999, a consequence of a drop in petroleum prices but also central state deadlock, placed a further strain on the relationship between local and national governments. The crisis affected Guayaquil in particular as the central government decided to recapitalize four banks and liquidate nine, five out of which were led by prominent Guayaquil elite families. At that point regional elites started to accuse the government of a pro-Quito bias, organizing widespread protests and a strike, which initiated the intensification of Guayaquil's autonomy movement (Eaton 2011).

Claims for Guayaquileño autonomy gained further force when Rafael Correa (2007-2017) running on an anti-establishment and anti-neoliberal platform - was elected president. His victory meant that the PSC, and by extension Guayaquil elites, lost much of their influence as political power shifted back towards the center. Correa blamed the rising autonomy demands in Guayaquil on the instability of the central state, which he sought to remedy through a nation-wide development programme. In 2008 he adopted a new constitution that granted national government greater control over monetary and oil policy. He also isolated Guayas from other Ecuadorian regions. In response, Guayaquil elites stepped up their mobilization for more autonomy (Burbano de Lara 2014).

\section{Catalonia}

Under Francisco Franco's (1939-1975) dictatorship Spain was a highly centralized state with Catalonia's political autonomy and its control over fiscal and administrative matters severely constrained. This changed with democratization. Similar to Ecuador, transition to democracy 
radically transformed center-region relations and strengthened the position of Catalan political elites. The Constitution of 1978 created 17 autonomous communities - including Catalonia - as a new level of regional government while the 1979 Statute of Autonomy granted these substate units the right to self-government and significant administrative control and far-reaching responsibilities over policy domains such as health, education, infrastructure, and culture. These quasi-federal arrangements were remarkably incoherent however and ultimately resulted in a loose institutional framework that encouraged constant political bargaining and led to enduring fiscal inequalities between the regions (Beramendi 2012; Colomer 2017).

That being said, during the 1980s and 1990s, Catalan political elites still exerted substantial political influence at the national level, especially because regional political parties could also participate in nationwide elections. The most powerful amongst them, the center-right Convergència $i$ Unió ( $\mathrm{CiU})$, tended to gain enough seats in national elections to potentially provide the two dominant parties in Spain, either the left-leaning Partido Socialista Obrero Español(PSOE) or the conservative Partido Popular (PP), with a critical number of votes needed to form a government (Beramendi 2012).

With the onset of the new millennium, the relationship between the central state and Catalonia changed. One important aspect of the transformation was the declining influence that Catalan regionalist parties held in Spanish politics. In the 2000 national elections the PP won with an overwhelming majority, which allowed it to rule without the support of other political parties and take a more centralist stance on territorial politics. Moreover, and similar to Bolivia and Ecuador, another contributing factor that placed a strain on the relationship between Catalonia and the Spanish state was an (ultimately failed) attempt at further decentralization. From 2003 onwards the Catalan regional government sought to reform the Catalan Statute of Autonomy. In 2006 it obtained an approval for its reform proposal, but in 2010 the Spanish constitutional court declared key aspects of the new statute unconstitutional, including the recognition of Catalonia as a nation, the preferential treatment of Catalan language over Castilian, and the capacity of the regional government to 
determine its own taxes at the local level. In response, both the Catalan political class and the wider public lost trust in the existing institutional arrangement of the Estado de autonomías, arguing that self-rule could no longer be achieved in cooperation with the central state (Colomer 2017; Keating and Wilson 2009).

Finally, the Great Recession (2007-2009), and more importantly the austerity measures implemented in its immediate aftermath, instigated further concerns about Catalonia's position within Spain. Much of the political fallout of the economic crisis was shouldered by Spain's regional governments as cuts to policy domains such as health and education fell under their direct responsibility (Guibernau 2013). Consequently, the "fiscal pact" between Catalonia and the central state was placed at the forefront of political debate, with both local left-leaning and conservative political forces agreeing that the arrangement is unjust and detrimental to Catalonia's quest for more, and not less self-determination.

In sum, the cross-regional comparison developed in this section has shown that recent territorial autonomy mobilizations in early $21^{\text {st }}$ century Santa Cruz, Guayas, and Catalonia share important similarities. In all three cases center-substate arrangements became increasingly contested, which subnational elites understood as threats of political exclusion that could erode their influence and power base.

\section{Changes in Civic Networks and New Movement-State Linkages}

While these threats crucially motivated the recent intensification of territorial autonomy protests in Santa Cruz, Guayas, and Catalonia, they cannot explain why those movements were capable of doing so. As social movement theorists frequently remind us, collective mobilization also requires the "right kind" of movement infrastructure - the organizational structures and resources that enable challengers to act collectively (Andrews 2001). Those usually include associational networks and civic associations that help connect previously unconnected collectivities, exchange information and plan specific protest campaigns. Increasingly, analysis of movement infrastructure also started to pay 
attention to resources activists derive from ties to political parties (Goldstone 2003) and state officials (Gibson 2018). Following this lead, the second part of our argument puts the analytical spotlight on organizational characteristics of territorial autonomy mobilizations in Santa Cruz, Guayas, and Catalonia. In all three regions territorial challengers were already comparatively well-organized at the onset of mobilization. During the $21^{\text {st }}$ century new movement-party and movement-state linkages crystallized. In fact, parts of the subnational state became subsumed into the movements and this breaching of the subnational state-society divide further facilitated protest activities and shaped the three territorial autonomy movements into their current form.

\section{Santa Cruz}

Bolivia has a densely organized and highly mobilized civil society with high levels of interconnectivity between grass-roots civic organizations, political parties, and state agencies (Vergara 2012). Seen in this light, it is not surprising that autonomy activism in Santa Cruz has been able to rely on a well-resourced movement infrastructure. The most important civil society organization spearheading the movement has been the Comité Pro Santa Cruz (CPSC). Founded as a resistance group during Bolivia's 1952 Revolution against the ultimately victorious MNR, the CPSC was the first organization of its kind in Bolivia, and its pioneering role in mobilizing opposition against the centralist MNR in La Paz endowed it with exceptional legitimacy (Eaton 2007). To this day the CPSC, having a huge membership base, remains the organizational backbone of the autonomy movement in Santa Cruz and provides it with critical resources for rallies and campaigns, including financial support, close ties to major business associations and linkages to various NGOs (Gustafson 2006).

During the 2000s, the autonomy movement expanded its reach and sought to co-opt groups that could potentially oppose its agenda. Accordingly, it started to selectively recruit lowland indigenous leaders into the organization and supported electoral campaigns of those with political ambitions. A telling example is the Guaraní leader Bonifacio Barrientos, who was nominated to the 
position of "Representative of the Indigenous Peoples of the Department to the CPSC," which allowed him to run for Congress in 2005 as a candidate of Bolivia's three traditional center-right parties. (Eaton 2007)

The Santa Cruz autonomy movement also benefitted from greater access to state resources. A leadership role in CPSC had long been an entry point for a political career. And after 2000, the boundaries between the movement and the regional state further blurred. Most prominently, in January 2005, CPSC unilaterally created a departmental assembly, forbidden by the constitution, and proclaimed its own president governor of Santa Cruz. Despite the Bolivian military's strong initial reaction, the pressure on President Carlos Mesa (2003-2006) was enormous and he agreed to hold elections for regional prefects, a public office for which the candidates were previously appointed by the central government. Former CPSC president Ruben Costas was elected the first regional prefect of Santa Cruz and subsequently supported the organization of a referendum on departmental autonomy in 2006 where the "Yes" side won with a resounding victory (Burbano de Lara 2014; Eaton 2011).

Increased support for autonomy activism also came from the private sector. Feeling threatened by Morales' left-leaning policies, a cross-section of Cruceño economic elites decided to form a united front against the central state. Ranging from local cattle ranchers to the chamber of industry and commerce, the hydrocarbons chamber and the agricultural chamber, they formed the Federación de Empresarios Privados de Bolivia-Santa Cruz (FEPB-SC). The FEPB-SC directed large sums of financial resources to the autonomy movement. There was also a great deal of interconnectivity among the main organizations involved in autonomy activism. Branko Marinkovic for example was president of FEPB-SC since 2004 while also serving as president of CPSC between 2007 and 2009 (Suso 2010).

Finally, the movement gained further strength from processes of internal diversification and radicalization. In 2000, Nación Camba was founded. Led by a group of former CPSC members, the organization advances an inclusive discourse towards lowland indigenous groups, as illustrated by 
the translation of campaign materials and other publications into the local Guaraní language. At the same time, Nación Camba takes an exclusionary stance towards indigenous peoples from the Andean highlands, and has at times even resorted to violence against peasant and indigenous protests. Within the context of the wider movement, the presence of Nación Camba, and its explicit promotion of the region's secession from Bolivia, provides other factions led by the CPSC with a convenient possibility to present their own demands for far-reaching autonomy as moderate and conciliatory (Gustafson 2006; Lowrey 2006).

\section{Guayas}

In Guayas, the Junta Cívica de Guayaquil (the Guayaquil Civic Board [JCG]) historically played a similar role to CPSC in Santa Cruz. The Board brings together different civic associations, activist networks, and powerful individuals, and has been at the forefront of protests and campaigns in favor of more autonomy. JCG has also been involved in cultural work, organizing and sponsoring activities that construct and promote a sense of a distinct Guayaquil identity (Burbano de Lara 2014).

The movement can also rely on close ties to national political actors and the local state administration, which can be traced back to Guayaquil's 1990s urban regeneration program. In 1992 former president León Febres-Cordero became mayor of the city, and under his leadership new public-private partnerships around ambitious renovation projects were formed: the JCG, together with the Gobernación del Guayas (a representative local body of the central government dominated by PSC), various universities, non-profit foundations, and chambers representing different private sector interests, became the municipality's main strategic partners. Over time, these partnerships strengthened the relationship between local administration and civil society groups, while also cultivating a sense of autonomy from the central state (Delgado 2013).

Echoing what happened in Santa Cruz, during the early 2000s the movement's organizational resources increased and movement-party linkages intensified in Guayas. JCG expanded its membership base, including the archbishop of Guayaquil, presidents of regional business chambers, 
directors of various mass media outlets, and several Ecuadorian ex-presidents (Eaton 2011). The movement also gained further support from political parties. In fact, relations with PSC became increasingly symbiotic. From the 2000s onwards, the party started to develop closer relationships with JCG and other civic associations in favor of territorial autonomy. An important impetus for this change in movement-party relations came in 1999 when Fuerza Ecuador, a self-defined think-tank that gradually converted into a social movement organization, collected 370,000 signatures while campaigning for a popular vote on Guayas' autonomy.

Another boost to the movement came from increasing control over the local state apparatus. Again similar to Santa Cruz, local political elites in Guayas such as mayors and prefects emerged as movement leaders. Most prominently, Jaime Nebot, Guayaquil's mayor from 2000 until 2019, continued Febres-Cordero's urban regeneration initiative. He also spearheaded major protest campaigns in favor of territorial autonomy. In 2008 he drew on municipal resources to organize a march that rejected Ecuador's proposed new constitution as a blatant recentralization effort that would exclude Guayaquil from most national-level decisions. Nebot instead called for holding a popular referendum on autonomy and organized mass rallies on symbolic dates such as "Guayaquil Independence Day" on October 9.

During the 2000s, it was the municipality of Guayaquil itself that thus became a major organizational platform of the Guayas autonomy movement. Nebot consciously avoided any overt political partisanship in his public appearances and management style and instead embraced a unifying discourse focused on civics, allowing the municipality to act as a civil society association on its own. This meant that the municipality became a de facto umbrella organization that coordinated mobilization efforts of civil society organizations with an explicit pro-autonomy stance of all kinds, including the Guayas historical archive, various universities, charities, foundations, the media, and chambers of industry and commerce.

At the same time, movement infrastructure remained more limited when compared to Santa Cruz (Eaton 2011). For one thing, even during the 2000s, the Guayas autonomy movement continued 
to be a predominantly elite-based project that did not reach out to indigenous groups or popular sectors. Moreover, at least since 2005, JCG has been weakened by an internal split when a faction of the association's membership separated after accusing JCG of being too conciliatory towards Correa's national government. During the 2000s, territorial autonomy activism in Guayas could thus rely on an expanding movement infrastructure, though probably one that was somewhat more fragmented and less powerful than its counterparts in Santa Cruz or Catalonia, as we will see below.

\section{Catalonia}

The Catalan territorial autonomy movement entered the recent episode of intensified mobilization with significant organizational resources already in place. Many civil society organizations that (re)emerged during democratization went on to become strong advocates for more regional autonomy, while civic associations with an outright separatist agenda remained at the margins of the movement. Pro-independence activism was also internally fragmented - between right-wing and leftist, moderate, and radical factions (Balcells 1996).

This changed in the $21^{\text {st }}$ century when pro-independence factions overcame their political divisions, gained in organizational strength, and ultimately managed to obtain a hegemonic position within the Catalan territorial autonomy movement. Especially at the local level activists were able to rely on new organizations to convoke mass demonstrations and protest rallies across Catalonia. The Assemblea Nacional Catalana (ANC) played an especially crucial role in this regard. Founded in 2011 and endowed with a rapidly expanding membership base and a highly decentralized organizational structure, its main objective became an independent Catalan state within the European Union. A further civil society organization at the forefront of the secessionist movement, Omnium Cultural, morphed from a cultural organization primarily concerned with Catalan language and literature into a political organization committed to the cause of Catalonia's independence. In the process, Òmnium increased its membership base from 20,000 to 160,000 in a matter of years, turning into the largest civil society association in Catalonia. (Crameri 2015) 
During 2010s linkages to regional political parties also proliferated. While in government from 1980 until 2003, the center-right CiU supported devolution but not secession, and ties to proindependence forces existed, if at all, at a personal level, between activists and individual politicians. But soon after the 2012 ANC-led Diada rally, the party changed its position on territorial politics and made the electoral promise of organizing a referendum on Catalan independence. Another indication of this increasingly symbiotic movement-party relationship was the formation of a new electoral alliance. Before the regional elections in September 2015, Catalan pro-autonomy associations and different regional parties formed the secessionist Junts pel Si ("Together for the Yes"). This electoral platform was led by Carme Forcadell as president of ANC and Muriel Casals as former president of Òmnium Cultural together with regional party leaders such as Oriol Junqueras (ERC) and Artur Mas (formerly CiU, now Convergència Democràtica de Catalunya [CDC]) (López 2015).

The 2015 elections, won narrowly by Junts pel Sì, also brought greater access to state resources. For the first time, well-known civil society leaders who explicitly advocated for Catalonia's independence from Spain ascended into regional-level public office. Raül Romeva, a former European parliament member and an Òmnium Cultural campaigner in the past, was the first person on the electoral list. After the elections, he was named Minister for External and Institutional Relations of Catalonia, a newly established position. Other notable civil society figures include Carme Forcadell, who became the President of the Parliament of Catalonia in 2015, a position she held until $2018 .^{1}$

Growing influence over mass media became another crucial pillar of secessionist mobilization (Crameri 2015; García 2013). TV3, Catalonia’s publicly funded television channel, has long fostered a sense of a distinct Catalan community and during the 2010s it turned into an important outlet for debates around Catalan independence. This is especially pertinent considering the fact that the majority of Catalans who support independence primarily watch Catalan TV channels with TV3 the most popular choice (Centre d'Estudis d'Opinió 2014). 
Taken together, both the expansion and greater cohesion of movement infrastructure facilitated the recent intensification of territorial autonomy mobilization in Catalonia. During the $21^{\text {st }}$ century, region-wide associational structures were formed, new linkages to political parties emerged, and (subnational) state-movement boundaries became blurred.

\section{Anti-Neoliberal Protest Cycles and Changing Framing Strategies}

In the previous two sections we have shown that threats of political exclusion, in tandem with changes in the movement infrastructure at the disposal of subnational challengers, played a central role in instigating and facilitating greater contention for territorial autonomy in Santa Cruz, Guayas, and Catalonia. This section develops the third and final aspect of our argument. We continue to follow the lead of social movement theory and focus on framing strategies - or the meaning construction and signifying work challengers employ in order to legitimate and gain societal support for their claims (Snow et al. 1986). Specifically, we maintain that the diagnostic frames employed by activists and civic associations in these three cases changed during the 2000s and 2010s, borrowing from broader indigenous and anti-neoliberal protest cycles, and that those transformed framing strategies became rather effective in garnering resonance among target audiences and/or the wider public.

\section{Bolivia and Ecuador}

A focus on framing reveals significant changes during 2000s. Concerned about their public depiction as criollo ("white") elite projects primarily focused on the preservation of privilege, territorial autonomy movements in Bolivia and Ecuador moved beyond emphasizing shared grievances about the distribution of state resources and a distinct territorial identity (Eaton 2011). In both cases, movement leaders increasingly engaged in the ethnicization of collective identities they claimed to represent and pursued what some scholars have described as ethnic boundary work - dividing the social world into "us" and "them" based on markers associated with shared ancestry, and offering scripts of action on how to relate to individuals from distinct ethnic categories (Wimmer 2008). 
In Bolivia, autonomy activism reinterpreted Cruceñidad as a pan-ethnic identity that cuts across different racial and social class backgrounds. Specifically, the movement departed from treating Cruceños as a loose civic category applied to everyone living in Santa Cruz, adding another layer of meaning to it. Cruceños, regardless of their ethnoracial, linguistic, and social class background, were now also described as Cambas, a once derogatory term used exclusively for lowland indigenous peoples in Bolivia (Fabricant 2009). The Cruceño-Camba identity refers not just to indigenous groups but to mestizos as well (a person of mixed race in Latin America), and serves as a way to bridge the relationship between non-indigenous (and often elite) Cruceños and lowland native peoples. The Santa Cruz movement thus constructed a romanticized version of "their own" lowland Guayaní, Chiquitano and Guarayu indigenous groups as "clean," “intelligent" and "industrious," juxtaposed to the so-called Kolla, a derogatory term for Bolivians from the Andean highland regions, depicted as "dirty," "stupid" and "lazy" Morales-supporters (Perreault and Green 2013).

In Ecuador a similar process can be observed. The autonomy movement actively promoted ethnicization of Guayaquileño identity, complementing its meaning as a predominantly territorial identity with a greater emphasis on cultural and historical distinctiveness. According to this perspective, Guayas is distinct because of its own cultural practices and traditions that cut across different social classes and ethnoracial groups, as for example manifested in its unique styles of music, dance, speech, and cuisine. Guayaquileño identity is also different because of its distinct historical roots, especially because Guayas declared independence from Spain earlier than the rest of the country did (Burbano de Lara 2014). That said, when compared to Santa Cruz and its emphasis on the Cruceño-Camba vs. Kolla cleavage, the autonomy movement in Guayas is probably less rigid in its emphasis on ethnic differences. Instead, it represented Guayaquil as the main defender of regionalism more broadly, and the central state as the main enemy to Ecuador's regions and their accompanying identities. $^{2}$ 
The framing of territorial autonomy protests as a legitimate expression of ethnic difference gained prevalence in public life. In Santa Cruz the movement incorporated various symbols of Cruceño-Camba identity into its immediate protest tactics and wider cultural work (Fabricant and Postero 2013). Mass demonstrations in favor of regional autonomy tended to include traditional indigenous folk performances, protestors often dressed up in clothing styles associated with rural agrarian life and lowland indigenous peoples, while carnivals and major holiday parades incorporated "Camba" food, music, and dance traditions (Gustafson 2006). And CPSC sought to rebrand itself as the embodiment of the Cruceño-Camba pan-ethnic identity through a symbolic (and widely publicized) move of inviting representatives of different lowland indigenous groups to join and become members of the organization (although, and this bears emphasis, in a subordinate, non-voting role) (Lowrey 2006). Similarly, in Guayas autonomy activism celebrated symbols of Guayaquileño identity in its various public activities while civic associations and NGOs associated with the movement engaged in more overt forms of boundary work, such as promoting a distinct regional Spanish.

The ethnicization of Cruceño and Guayaquileño identity, manifested in the new framing strategies employed by Cruceño and Guayaquileño autonomy mobilizations, need to be situated within a wider protest cycle namely, the rise of indigenous movements in Latin America. Indigenous peoples recently became a formidable political force in their own right, and their movements have aspired to achieve territorial rights, greater control over resources, political power, and a recognition of their subjectivities within official understandings of national identity and history (Lucero 2008; Van Cott 2005; Trejo 2012). By drawing on the multicultural rights discourse advanced by indigenous actors, territorial autonomy movements in Santa Cruz and Guayas sought to represent their movements as part of the same struggle for multicultural group rights. They criticized the central state for recognizing and enforcing the demands advanced by indigenous groups in the Andean highlands while systematically neglecting the same territorial rights to Cruceños and Guayaquileños - as ethnic groups. A paradox, given the fact that these territorial autonomy movements were essentially counter- 
movements motivated at least in part by the supposed threats indigenous politics posed to established territorial arrangements and the distribution of state resources.

\section{Catalonia}

When compared to Santa Cruz and Guayas, the ethnicization of Catalan identity was already more pronounced. During the $19^{\text {th }}$ century, a cultural movement known as Renaixença sought to revive Catalan language and culture based on the romanticized idea of a medieval Catalan nation. The Cultural and linguistic distinctiveness of Catalan identity was afterwards successfully reinforced through mass schooling in Catalan (Balcells 2013).

Similar to the two Latin American cases however, during the 2010s a new diagnostic frame started to inform territorial autonomy mobilizations in Catalonia. In order to justify demands for secession, activism moved beyond the notion of a distinct Catalan identity and the unjust distribution of state resources between the different autonomous communities, and instead emphasized the idea of participatory democracy, and a lack thereof in Spain. According to this problem definition, the country's current political system might be formally democratic, but it remains largely unresponsive to citizen demands and therefore lacks popular legitimacy. For the Catalan territorial autonomy movement this deafness is powerfully illustrated by the categorical refusal of different national governments to allow a referendum on Catalan independence to go forward. By denying Catalan people "the right to decide," political elites in Madrid would show their inherently undemocratic orientation. In this narrative, then, mobilizations for Catalan independence are not an expression of a center-periphery cleavage but intrinsically connected to the struggle for more direct and plebiscitary forms of democracy (Barrio et al. 2018, 1011).

The direct democracy frame quickly achieved wider public resonance. The 2010 mass demonstration in support of Catalonia's new Statute of Autonomy (and against the ruling by Spain's Constitutional Court) embraced the slogan "We are a nation, we decide," yet its meaning was still not fully settled with respect to national independence (Crameri 2015). Two years later, however, any 
ambivalence was gone. The banners and speeches at the marches celebrating the Diada (Catalonia's national holiday) in 2012, and the even larger events in 2013 and 2014, advocated "the right to decide," which then unambiguously referred to a popular vote on Catalonia's independence from Spain (Humlebæk and Hau 2020). The direct democracy frame also came to inform other protest tactics. The publicity work, education campaigns, and the cultural artifacts (e.g., books, video, podcasts) produced by social movement organizations such as ANC and Omnium represented a referendum on national independence as an expression of the will of the Catalan people and a pinnacle of participatory democracy. The central government's repression of the 2017 unilateral and unconstitutional referendum on Catalan independence added further fuel to the secessionist campaign's claim that Spain is an undemocratic state. The crackdown, which included police raids, imprisonments of the main political and activist figures, and violent dispersals of voters on the day of the referendum, led to a short-term increase in support for independence while it also strengthened attitudes of animosity towards Spanish central government and the EU (Balcells, Dorsey, and Tellez 2020).

Catalan independence activism was not alone in its assessment of the Spanish political system as beset by democratic deficit and fundamental political legitimacy issues. In fact, the intensification of secessionist mobilization coincided with and was part of a wider anti-neoliberal protest cycle ${ }^{3}$ against austerity measures introduced by governments in Europe during the immediate aftermath of the Great Recession (2007-2009). In Spain the rise of the so-called Indignados took everyone by surprise. This powerful and highly consequential movement brought millions of people onto the streets for recurrent protests and marches in 2011 and 2012, while basing its strength on many new activist networks and organizations that were previously absent from Spain's political landscape (Ancelovici 2015). One of the main Indignado diagnostic frames identified a glaring democratic deficit and the resulting subjugation of politics to economics as the root problem that triggered the crisis in the first place and then shaped the austerity measures by which the government responded. 
Accordingly, the Indignados advocated for more direct forms of democracy in order to involve citizens in the management of the economic crisis (Asara 2016).

Seen in this light, anti-neoliberal mobilization that swept through Spain (and other countries in the Iberian world) from 2011 onwards, provided other movements, including the Catalan secessionist movement, with a transformed discursive repertoire. The Indignados' push for a more inclusive and democratic political system and the expansion of participatory mechanisms was echoed in the transformed framing strategy of the Catalan territorial autonomy movement: Its representation of the Spanish state as inherently undemocratic and secessionist mobilization as an act of direct democracy was inspired by the Indignados' critique of representative democracy and their vision of introducing "real democracy" to overcome austerity and the logic of economism.

\section{Conclusion}

This article has presented a systematic cross-regional comparison of distinct, but analytically related episodes of contention in Catalonia, Santa Cruz, and Guayas. The conceptualization of these mobilizations as territorial autonomy movements has allowed us to move beyond the contrast between state-seeking nationalism in Europe and its relative absence in Latin America, and instead develop a cross-regional perspective on social movements that seek to alter the existing spatial organization of the polity. We have further drawn on social movements theory to develop a multicausal account focused on structural opportunities, threats, resources, and framing strategies to explain why territorial autonomy mobilization recently increased in these three cases.

A question that remains is why during the recent contentious episode in Catalonia independence from Spain came to be the dominant demand, while territorial autonomy movements in Santa Cruz and Guayas largely abstained from secessionist claims-making. Some analysists have focused on economic expectations and emphasize an increase in expected material benefits from Catalan independence in the aftermath of the Great Recession (Boylan 2015; Duerr 2016; and with some qualifications Muñoz and Tormos 2015). Other civil society-focused explanations point to the 
“discursive trapping” of mainstream Catalan parties by independentist associational networks (Basta 2018) or the broad-based mobilization effects of an earlier wave of informal municipal referenda on Catalan independence between 2009 and 2011 (Muñoz and Guinjoan 2013). Finally, political competition arguments point to growing party radicalization and ethnic outbidding dynamics at both national and subnational levels (Barrio and Teruel 2017; Colomer 2017), as well as intensified competition for state resources between Madrid and Barcelona as global cities (Jordana 2019). While a fully-developed engagement with this debate would move the article beyond its original research question, our cross-regional approach does put a number of factors - some already highlighted by specialists on Catalan nationalism - into sharp relief. Certain structural conditions conducive to separatist mobilization - most importantly, the supranational context of the EU which the Catalan movement has argued Catalonia would remain a part of in case of achieving independence (although this was later rejected by the EU itself), a well-established subnational party system, the presence of a distinct, territorially-bounded language as a mobilizing cleavage, and overall greater decentralization in Spain - are not present in the cases of Santa Cruz and Guayas and thus provide promising leads to account for the growing hegemony of separatism in Catalonia.

Our cross-regional comparison of territorial autonomy movements also engages a number of broader issues in research on regionalism and secession. Most importantly, it provides an important corrective to distributist arguments and their sole focus on a wealth maximization rationale as the key to explain where and when ethno-territorial mobilizations arise (Bolton and Roland 1997; Collier and Hoeffler 2011). In this perspective, better-off regions perceive secession or autonomy as a way to avoid sharing state resources and subsidizing less prosperous regions. Comparing Santa Cruz, Guayas, and Catalonia reveals that distributist arguments are useful for indicating relevant structural conditions that are conducive to the formation of territorial autonomy movements. However, when taken by themselves they lead to a line of reasoning that is too static and cannot explain changes in the intensity and form of autonomy activism over time. Moreover, our contentious politics-inspired approach cautions against arguments that link territorial autonomy mobilization directly to economic 
crises. At a first glance it is tempting to connect the rise of secessionism in Catalonia during the 2010s to the effects of the Great Recession (Boylan 2015; Duerr 2016) and the fear of losing goods and rights associated with the crisis. Yet, as the cases of Santa Cruz and Guayas demonstrate, territorial autonomy movements might also gain force in contexts of sustained economic growth. ${ }^{4}$

We further suggest that the applicability of our framework is not limited to Bolivia, Ecuador, and Spain, and argue that our approach potentially yields insights into cases situated outside the Iberian world. For example, the Western Cape province, South Africa's economic powerhouse characterized by a demographic composition that is distinct from the rest of the country, has recently seen the increase of mobilization in favor of territorial autonomy. While most activist groups seek greater political control and more cultural rights, some movement organizations such as the predominantly Coloured (mixed-race) Gatvol Capetonian and the primarily white Cape Party advocate for a "Wexit," or secession from South Africa. Our framework suggests that a crucial motivating factor behind these mobilizations - in tandem with endemic corruption and graft that marred the Jacob Zuma (2009-2018) government - has been the centralization of state power in Johannesburg and the reduction of South African provinces to second-tier administrative units. Moreover, the Western Cape autonomy movement greatly benefitted from the organizational resources provided by the recent "reemergence" of civil society activism and the rise of antiestablishment movements in the country. At the same time, the intensity of mobilization has arguably been more muted, especially when compared to movements in Bolivia, Ecuador, and Spain. Based on the framework developed in this article we suggest that this is likely related to the movement's framing strategies. Those remain exclusionary and ultimately rooted in associations with Afrikaner (white) nationalism and/or anti-black racism and have thus been unable to achieve wider public resonance (Cornelissen and Horstmeier 2002; Jacobs 2018).

Another example comes from post-Suharto Indonesia, which has a long history of territorial autonomy mobilizations. The Minahasa regency in the province of North Sulawesi, home to one of these movements, represents a major trading center in the new regional growth triangle with southern 
Philippines, Brunei, and East Malaysia. Minahasans - in their majority Christians - constitute North Sulawesi's politically most powerful ethnic group. During the 2000 s, in the immediate aftermath of Indonesia's democratization, Minahasa mobilization intensified, advancing demands for a separate autonomous province within North Sulawesi. Crucial drivers behind this contentious episode were the 1999 new decentralization law but also growing concerns among Minahasa elites about their political influence, given the growing power of political Islam in national politics and a Javanesedominated central government. Democratization also meant that the movement benefited from the overall proliferation of civil-society organizations and the global human rights discourse. Similar to the other cases examined in this article, the Minahasa autonomy movement embarked on a vigorous cultural revival campaign. A dense network of intellectual elites, local community leaders, university scholars and students, local NGOs and other movement organizations started to promote an overarching sense of collective identity despite various linguistic and cultural differences amongst numerous Minahasa sub-groups. To achieve this, the movement made use of ethnic symbols, relied on local newspapers and social media platforms, held a congress to petition the central government, sponsored academic publications, and attempted to revise school curriculums to teach pre-colonial cultures in local languages. The movement framed their campaign by evoking a right to culture and identity as a basic human right (Jacobsen 2002; Amin 2012).

While a full elaboration of these case studies is obviously beyond the scope of this article, they nonetheless illustrate the usefulness of our conceptual lens and set the stage for systematic comparative research on territorial autonomy movements. In fact, we hope that the cross-regional perspective introduced in this article encourages scholars to further develop a research program that moves beyond the often rather regionally bound literatures on (subnational) regionalism and secessionism.

Disclosures. None 
Funding Information: The research leading to this study received funding from the Spanish Ministry of Research, Development, and Innovation under the Ayudas Ramón y Cajal incorporation program held by Dr. Matthias vom Hau (RYC-2014-16774).

Acknowledgements: We are grateful to Miguel Centeno, Eduardo Dargent, Agustín Ferraro, Antonio Lucero, Alan Knight, Luciana de Souza Leão, and the two anonymous reviewers for comments on earlier drafts of this article. 


\section{References}

Almeida, Paul D. 2003. "Opportunity organizations and threat-induced contention: Protest waves in authoritarian settings." American Journal of Sociology 109 (2): 345-400.

Amin, Basri. 2012. "Ethnic Identity in Colonial and Postcolonial Politics: The Case of Minahasa, Eastern Indonesia." Journal of Asia Pacific Studies 2 (3): 322-346.

Ancelovici, Marcos. 2015. "Crisis and Contention in Europe: A Political Process Account of AntiAusterity Protests.” In Europe’s Prolonged Crisis, edited by Hans-Jörg Trenz, Carlo Ruzza, and Virginie Guiraudon, 189-209. London: Palgrave Macmillan UK.

Andrews, Kenneth. 2001. "Social Movements and Policy Implementation: The Mississippi Civil Rights Movement and the War on Poverty, 1965-1971.” American Sociological Review 66: $71-95$.

Asara, Viviana. 2016. “The Indignados as a Socio-Environmental Movement: Framing the Crisis and Democracy." Environmental Policy and Governance 26 (6): 527-542.

Balcells, Albert. 1996. Catalan Nationalism: Past and Present. New York: Palgrave.

Balcells, Laia. 2013. "Mass Schooling and Catalan Nationalism," Nationalism and Ethnic Politics 19 (4): 467-486.

Balcells, Laia, Spencer Dorsey, and Juan F. Tellez. 2020. "Repression and Dissent in Contemporary Catalonia." British Journal of Political Science: 1-9.

Barrio, Astrid, and Juan Rodríguez-Teruel. 2017. "Reducing the gap between leaders and voters? Elite polarization, outbidding competition, and the rise of secessionism in Catalonia." Ethnic and Racial Studies 40 (10): 1776-1794.

Barrio, Astrid, Oscar Barberà, and Juan Rodríguez-Teruel. 2018. “'Spain steals from us!' The 'populist drift' of Catalan regionalism." Comparative European Politics 16: 993-1011.

Basta, Karlo. 2018. "The Social Construction of Transformative Political Events.” Comparative Political Studies 51 (10): 1243-1278. 
Beramendi, Pablo. 2012. "Endogenous Decentralization and Welfare Resilience: Spain, 1978-2007." In The Political Geography of Inequality: Regions and Redistribution, edited by Pablo Beramendi, 175-206. Cambridge: Cambridge University Press.

Boix, Carles. 2002. L'obertura Catalana. Barcelona: Centre d'Estudis de Temes Contemporanis. Bolton, Patrick, and Gérard Roland. 1997. "The Breakup of Nations: A Political Economy Analysis." The Quarterly Journal of Economics 112 (4): 1057-1090.

Boylan, Brandon M. 2015. "In pursuit of independence: The political economy of Catalonia's secessionist movement." Nations and Nationalism 21 (4): 761-785

Burbano de Lara, Felipe. 2014. La revuelta de las periferias: Movimientos regionales y autonomías políticas en Bolivia y Ecuador. Quito: Flacso Ecuador.

Cederman, Lars-Erik, Andreas Wimmer, and Brian Min. 2010. "Why do ethnic groups rebel? New Data and Analysis.” World Politics 62 (1): 87-119.

Centeno, Miguel Angel. 2002. Blood and Debt: War and the Nation-State in Latin America. University Park, PA: The Pennsylvania State University Press.

Centre d'Estudis d'Opinió. 2014. Baròmetre d'Opinió Pública: la onada 2014. http://upceo.ceo.gencat.cat/wsceop/4888/Taules\%20estad\%C3\%ADstiques\%20-746.pdf (Accessed December 15, 2020.)

Chiriboga-Tejada, Andrés. 2018. "A tale of two cities: the regional dimension of the Ecuadorian securities market." Economic Sociology: The European Electronic Newsletter 19 (3): 25-35.

Coggins, Bridget. 2014. Power Politics and State Formation in the Twentieth Century: The Dynamics of Recognition. Cambridge: Cambridge University Press.

Collier, Paul, and Anke Hoeffler. 2011. “The Political Economy of Secession.” In Negotiating SelfDetermination, edited by Hurst Hannum and Eileen F. Babbitt, 37-61. Lanham: Lexington Books.

Colomer, Josep P. 2017. “The venturous bid for the independence of Catalonia.” Nationalities Papers 45 (5): 950-967. 
Cornelissen, Scarlett, and Steffen Horstmeier. 2002. "The Social and Political Construction of Identities in the New South Africa: An Analysis of the Western Cape Province.” The Journal of Modern African Studies 40 (1): 55-82.

Cornell, Svante E. 2002. "Autonomy as a Source of Conflict: Caucasian Conflicts in a Theoretical Perspective." World Politics 54 (2): 245-276.

Crameri, Kathryn. 2015. "Political Power and Civil Counterpower: the Complex Dynamics of the Catalan Independence Movement." Nationalism and Ethnic Politics 21 (1): 104-120.

Cuadras-Morató, Xavier, and Toni Rodon. 2018. “The dog that didn’t bark: on the effect of the Great Recession on the surge of secessionism.” Ethnic and Racial Studies 42 (12): 2189-2208.

De la Calle, Luis, and Thomas Jeffrey Miley. 2008. "Is there more assimilation in Catalonia than in the Basque Country? Analyzing dynamics of assimilation in nationalist contexts.” European Journal of Political Research 47: 710-736.

Delgado, Alina. 2013. “Guayaquil.” Cities 31: 515-532.

Duerr, Glen M. E. 2016. “The European Economic Crisis and Rising Secessionism: New Demands on the European Social Model in Scotland, Flanders, and Catalonia.” In The European Social Model Adrift: Europe, Social Cohesion and the Economic Crisis, edited by Serena Romano and Gabriella Punziano, 151-169. London: Routledge.

Eaton, Kent. 2007. "Backlash in Bolivia: Regional Autonomy as a Reaction Against Indigenous Mobilisation.” Politics and Society 35 (1): 71-102.

Eaton, Kent. 2011. “Conservative Autonomy Movements: Territorial Dimensions of Ideological Conflict in Bolivia and Ecuador." Comparative Politics 43 (3): 291-310.

Fabricant, Nicole. 2009. "Performative politics: The Camba countermovement in eastern Bolivia." American Ethnologist 36 (4): 768-783.

Fabricant, Nicole, and Nancy Postero. 2013. "Contested Bodies, Contested States: Performance, Emotions, and New Forms of Regional Governance in Santa Cruz, Bolivia." The Journal of Latin American and Caribbean Anthropology 18 (2): 187-211. 
García, César. 2013. "Strategic communication applied to nation building in Spain: The experience of the Catalan region." Public Relations Review 39 (5): 558-562.

Gibson, Christopher L. 2018. "Programmatic Configurations for the Twenty-First-Century Developmental State in Urban Brazil.” Sociology of Development 4 (2): 169-190.

Goldstone, Jack. 2003. "Introduction: Bridging Institutionalized and Noninstitutionalized Politics." In States, Parties, and Social Movements, edited by Jack Goldstone, 1-26. New York: Cambridge University Press.

Gootenberg, Paul. 1991. "North-South: Trade Policy, Regionalism and Caudillismo in PostIndependence Peru.” Journal of Latin American Studies 23 (2): 273-308.

Gray Molina, George. 2008. "State-Society Relations in Bolivia. The Strength of Weakness." In Unresolved Tensions: Bolivia. Past and Present, edited by John Crabtree and Laurence Whitehead, 109-124. Pittsburgh: University of Pittsburgh Press.

Guibernau, Montserrat. 1998. Nations without States: Political Communities in a Global Age. Hoboken, NJ: Wiley.

Guibernau, Montserrat. 2013. "Secessionism in Catalonia: After Democracy.” Ethnopolitics 12 (4): $368-393$.

Gustafson, Bret. 2006. "Spectacles of Autonomy and Crisis: Or, What Bulls and Beauty Queens have to do with Regionalism in Eastern Bolivia." Journal of Latin American Anthropology 11 (2): $351-379$.

Hechter, Michael. 1992. “The Dynamics of Secession.” Acta Sociologica 35 (4): 267-283.

Hierro, María José, and Didac Queralt. 2021. “The Divide Over Independence: Explaining Preferences for Secession in an Advanced Open Economy." American Journal of Political Science. Published online ahead of print August 20, 2020. doi: https://doi.org/10.1111/ajps.12549

Humlebæk, Carsten, and Mark. F. Hau. 2020. "From National Holiday to Independence Day: Changing Perceptions of the 'Diada."' Genealogy 4 (1): 1-24. 
Jacobs, Sean. 2018. “The Limits of Coloured Nationalism.” Mail \& Guardian, June 13. https://mg.co.za/article/2018-06-13-00-the-limits-of-coloured-nationalism/ (Accessed December 30, 2020.)

Jacobsen, Michael. 2002. "On the Question of Contemporary Identity in Minahasa, North Sulawesi Province, Indonesia." Asian Anthropology 1 (1): 31-58.

Jordana, Jacint. 2019. Barcelona, Madrid y el Estado: Ciudades globales y el pulso por la independencia en Cataluña. Barcelona: Libros de la Catarata.

Keating, Michael. 1996. Nations against the State: The New Politics of Nationalism in Quebec, Catalonia and Scotland. London: Palgrave Macmillan.

Keating, Michael, and Alex Wilson. 2009. "Renegotiating the State of Autonomies: Statute Reform and Multi-level Politics in Spain.” West European Politics 32 (3): 536-558.

Laitin, David D. 2001. "Secessionist Rebellion in the Former Soviet Union." Comparative Political Studies 34 (8): 839-861.

Lawrence, Adria K. 2013. Imperial Rule and the Politics of Nationalism: Anti-Colonial Protest in the French Empire. Cambridge: Cambridge University Press.

Lopes de Souza, Marcelo. 2016. "Lessons from Praxis: Autonomy and Spatiality in Contemporary Latin American Social Movements.” Antipode 48 (5): 1292-1316.

López, Lucía P. 2015. “The 'Citizen Participation Process’ in Catalonia: Past, Present and Future.” Liverpool Law Review 36: 237-256.

Lowrey, Kathleen. 2006. "Bolivia Multiétnico y Pluricultural, Ten Years Later: White Separatism in the Bolivian Lowlands.” Latin American and Caribbean Ethnic Studies 1 (1): 63-84.

Lucero, José Antonio. 2008. Struggles of Voice: The Politics of Indigenous Representation in the Andes. Pittsburgh: University of Pittsburgh Press.

Lustick, Ian S., Dan Miodownik, and Roy J. Eidelson. 2004. "Secessionism in Multicultural States: Does Sharing Power Prevent or Encourage It?” The American Political Science Review 98 (2): 209-229. 
Mahoney, James. 2010. Colonialism and Postcolonial Development: Spanish America in Comparative Perspective. New York: Cambridge University Press.

Mares, David R. 2001. Violent Peace: Militarized Interstate Bargaining in Latin America. New York: Columbia University Press.

McAdam, Doug. 1982. Political Process and the Development of Black Insurgency, 1930-1970. Chicago, IL: The University of Chicago Press.

Muñoz, Jordi, and Marc Guinjoan. 2013. "Accounting for internal variation in nationalist mobilization: unofficial referendums for independence in Catalonia (2009-11)." Nations and Nationalism 19 (1): 44-67.

Muñoz, Jordi and Raül Tormos. 2015. "Economic expectations and support for secession in Catalonia: between causality and rationalization.” European Political Science Review 7 (2): $315-341$.

Núñez, Xosé-Manuel. 1999. “Autonomist regionalism within the Spanish state of the autonomous communities: An interpretation.” Nationalism and Ethnic Politics 5 (3-4): 121-141.

Pachano, Simón. 2006. "Ecuador: The provincialisation of representation." In The Crisis of Democratic Representation in the Andes, edited by Scott Mainwaring, Ana María Bejarano, and Eduardo Pizarro Leongómez, 100-132. Redwood City: Stanford University Press.

Perreault, Tom, and Barbara Green. 2013. "Reworking the Spaces of Indigeneity: the Bolivian Ayllu and Lowland Autonomy Movements Compared.” Environment and Planning D: Society and Space 31 (1): 43-60.

Polletta, Francesca, and James M. Jasper. 2001. "Collective Identity and Social Movements.” Annual Review of Sociology 27 (1): 283-305.

Rubin, Jeffrey W. 1997. Decentering the Regime: Ethnicity, Radicalism and Democracy in Juchitán, Mexico. Durham, NC: Duke University Press. 
Snow, David A., E. Burke Rochford, Jr., Steven K. Worden, and Robert D. Benford. 1986. "Frame Alignment Processes, Micromobilization, and Movement Participation.” American Sociological Review 51 (4): 464-481.

Soifer, Hillel David. 2016. "Regionalism, Ethnic Diversity, and Variation in Public Good Provision by National States." Comparative Political Studies 49 (10): 1341-71.

Sorens, Jason. 2005. "The Cross-Sectional Determinants of Secessionism in Advanced Democracies." Comparative Political Studies 38 (3): 304-326.

Suso, Roger. 2010. "Territorial Autonomy and Self-Determination Conflicts: Opportunity and Willingness Cases from Bolivia, Niger, and Thailand.” (Working Paper No.2010/1:1-70, International Catalan Institute for Peace).

Tarrow, Sidney. 1998. Power in Movement: Social Movements and Contentious Politics. Cambridge: Cambridge University Press.

Tilly, Charles. 1978. From Mobilization to Revolution. Reading, MA: Addison-Wesley. Tilly, Charles. 2005. Social Movements, 1768-2004. Boulder, CO: Paradigm Publishers.

Trejo, Guillermo. 2012. Popular Movements in Autocracies: Religion, Repression, and Indigenous Collective Action in Mexico. Cambridge: Cambridge University Press.

Van Cott, Donna L. 2005. From Movements to Parties in Latin America: The Evolution of Ethnic Politics. Cambridge: Cambridge University Press.

Vergara, Alberto, P. 2012. “Conflicto regional, estado central y sociedad periférica en Bolivia y Perú. Un análisis histórico comparado.” PhD diss., Université de Montréal.

Wimmer, Andreas. 2002. Nationalist Exclusion and Ethnic Conflict: Shadows of Modernity. Cambridge: Cambridge University Press.

Wimmer, Andreas. 2008. "The Making and Unmaking of Ethnic Boundaries: A Multilevel Process Theory." American Journal of Sociology 113 (4): 970-1022.

Wimmer, Andreas, and Brian Min. 2009. "The Location and Purpose of Wars Around the World: A New Global Dataset, 1816-2001.” International Interactions 35 (4): 390-417. 
Yashar, Deborah. 2005. Contesting Citizenship in Latin America: The Rise of Indigenous Movements and the Postliberal Challenge. Cambridge: Cambridge University Press.

\footnotetext{
${ }^{1}$ It bears emphasis, however, that expansion of linkages between pro-independence activism and local state administration was already an established pattern at the municipal level. After 2006, a significant part of mayors and local council members elected in Catalonia ran as self-declared independentistes (Muñoz and Guinjoan 2013).

${ }^{2}$ This might have been because Guayaquil was historically very potent while Santa Cruz only rose to prominence in the 1950s and 1970s in particular. The feeling of Guayaquil's "separate" identity was thus far more established already. Moreover, the indigenous cleavage is not as influential in Ecuador as in Bolivia, where a far larger part of the population identifies as indigenous.

${ }^{3}$ Protest cycles are phases of heightened contention between governments, challengers, and counter-movements that are usually characterized by the rapid dissemination of protest and the creation of or major changes in framing strategies (Tarrow 1998).

${ }^{4}$ Cuadras-Morató and Rodon (2018) also do not find empirical support for economic crisis as a driver of secessionism in Catalonia.
} 